\title{
Student Teachers' Reflective Practice on a Tutorial Teaching Approach
}

\author{
Kuang-yun Ting ${ }^{1}$ \\ ${ }^{1}$ Department of Applied English, St. John's University, Taiwan \\ Correspondence: Kuang-yun Ting, Department of Applied English, St. John's University, Taiwan. E-mail: \\ sandrine@mail.sju.edu.tw
}

$\begin{array}{lc}\text { Received: April 20,2013 Accepted: May 15, } 2013 \quad \text { Online Published: June 24, } 2013 \\ \text { doi:10.5539/ies.v6n7p150 } & \text { URL: http://dx.doi.org/10.5539/ies.v6n7p150 }\end{array}$

\begin{abstract}
The research explored the reflective practice of student teachers on efforts to improve how student teachers learn from their experiences of tutorial teaching in school. Tutoring means teachers working with individual students to support their learning. During this project, eight student teachers tried to help underachieving high school students improve their vocabulary confidence, learning skills and their memorising strategies so that the students could remember more vocabulary and use it more appropriately. Meanwhile, their self-confidence in English language learning could be developed. 16 junior high school students in Grade One were tutored once a week for 30 minutes, more than 10 successive weeks on the use of certain English lexical items. The tutorials took place from March to June in 2010 at a high school in an EFL (English as a Foreign Language) context. Eight student teachers were the tutors providing instruction, practice in pronunciation and vocabulary usage. The students who received the tuition made significant progress in word recognition. The results indeed showed that the young learners had benefitted from the eight student teachers' teaching methods. This project was intended to help junior high school students learn more vocabulary through the tuition of student teachers. Its success lies also in the fact that the eight student teachers were able to realise their ideas about effective vocabulary teaching and allowed them to appreciate the value of individual tuition.
\end{abstract}

Keywords: student teachers, tutorial teaching

\section{Introduction}

In the EFL country, the classroom may be the only place for students to learn and use English. However, it is very difficult for teachers to look after a class with an average of over 30 students. Thus, teachers usually spend much time on elicitation and instruction. For this reason, learners' individual needs are ignored in a class. However, the tutorial teaching approach is an active and effective teaching method from teachers' experience. The role of a tutor is to encourage students to engage with the learning problems they encounter and reconstruct their own understanding. Students expect individualized instruction from their teachers to enhance their educational and motivational outcomes. In fact, the tutorial teaching approach offers student teachers an opportunity to practise teaching with actual instructional responsibilities. When they give instruction, they must organize subject matter for classroom presentation. A tutorial teaching approach enables teachers to guide their students through learning by doing. Moreover, it provides opportunities for student teachers to evaluate their effectiveness as a teacher. Accordingly, the research in general uses the theory of reflective practice, a model of teacher decision making. Teachers plan, act, evaluate and reconceptualise in order to develop their new action and new thinking. This study tries to explore an understanding of student teacher learning within these contexts of practice. Therefore, the review emphasizes tutoring teaching and reflective practice.

\section{Literature Review}

\subsection{Tutoring Teaching}

As tutorial teaching is defined, a tutor guides an individual or a small group of students. In the meantime, students expect that such tutorials can help them make better sense of the subject matter and promote their essential academic skills (Ashwin, 2005). As they see the significance and implications of their knowledge with the help of discussion in tutorials, they can apply the knowledge they have learned to use new contexts. Similarly, both tutors and students may be encouraged and accomplished by such a kind of particular education experience. After discussing the area of difficulty with the students, the tutor can offer an opportunity for continuous feedback. Indeed, student feedback plays a vital role in reflective practices, which is emphasized upon by 
Brookfield (2000) because student feedback and advice are helpful to their teachers or tutors in reforming their teaching styles for their future teaching practice.

Researchers have recognised that tutorials allow students to pursue their personal academic interests within the context of their subject. The tutorial system, with its smaller classes, presents a teaching context that allows a student-centred teaching approach can be used (Prosser \& Trigwell, 1997). Additionally, it utilizes a learning approach with an emphasis on the development of an individual understanding of the course materials (Gow \& Kember, 1993). This is of great significance because students with a deep learning approach are apt to obtain better results in terms of learning outcomes than those students with a surface learning approach (Prosser \& Trigwell, 1999). Therefore, there seems to be a relationship between the ways in which academics deal with their teaching and the quality of their students' learning outcomes.

A good tutorial teaching approach will inspire, exact, challenge and be fulfilling for tutors and students alike. Some experienced tutors offer brilliant tutorials and many do it very well, without ever clearly stating any theory as an explanation for their actions. However, how are novice tutors to develop their teaching common-sense by combining scholarly knowledge, practice, and sound common sense? The top priority is that teachers should consider their own experiences when applying knowledge to practice. This notion is echoed in the principle of reflective practice which is discussed in next section.

\subsection{Reflective Practice}

In education, reflective practice refers to the process of teachers studying their own teaching methods and determining which is the most efficient for the students, including the consideration of ethical consequences of classroom procedures on students (Zeichner \& Liston, 1987). Reflection-in-action assists teachers in making the professional knowledge obtained from their teaching experience an explicit part of their decision-making (Schön, 1983). Educators can evaluate their teaching methods and get improvement by using criteria (Schön, 1987). Moreover, reflective practice pushes teachers from their knowledge base of distinct skills to modify their skills to suit specific contexts and situations, and eventually to invent new strategies (Larrivee, 2000). In other words, teachers will be able to move themselves, and their schools, beyond existing theories in practice while implementing a process of reflective practice.

The main advantage of reflective practice is to positively affect professional growth and development leading to the development of new knowledge of professional practice and to a broader understanding of the problems that practitioners face (Osterman, 1990). Therefore, reflective practice can help practitioners develop professionally. When professional development is promoted effectively, a teacher's practice in an educational setting will improve correspondingly (Pollard, 2008). Larrivee (2000) identifies four distinct levels of reflection described as follows:

Level 1 - Pre-reflection: at this level of reflection things are considered as true and accepted unquestionably. Teachers firmly believe situations to be dealt with beyond their control, but such reflections are superficial.

Level 2 - Surface Reflection: at this level reflections emphasize realizing specific objectives and standards. Reflections are supported by evidence with an increasing awareness of aiding different learners.

Level 3 - Pedagogical Reflection: at this level the teacher evaluates his or her action in the classroom and considers how the impact upon pupil learning.

Level 4 - Critical Reflection: at this level on-going reflection and critical inquiry into teaching actions and thinking processes are centralized significantly. In short, reflective practice is one of the leading means to enhancing not only a teacher's professional development but also their educational practices. In order to understand the experiences of the tutorial approach by students, two research questions are put forward to provide insight information.

1) What did the students taught by these student teachers perceive about the tutorial teaching approach?

2) What did the student teachers think of what they had learned to teach at the end of their initial teaching practice?

\section{Methodology}

\subsection{Research Design}

This project was undertaken at a university of science and technology and a junior high school in an EFL (English as a Foreign Language) context. It began in March and ended in June in 2010, lasting nine weeks.

As for all the student teachers, this was their first time teaching junior high school students and using a tutorial 
approach, and a continuous reflective practice played a crucial role in making sense of their work environment and initiating changes to support learning (Norton, 2009; Whitehead \& McNiff, 2006). Therefore, the research project was conducted using a self-reflective methodology. The research procedures were processed through three reflective stages.

1) Identify the language needs of learners.

2) Teach language lessons to address those needs.

3) Apply useful learning strategies tutoring an individual student.

At the first stage, the student teachers had junior high school students take a pre-test on English vocabulary to assess their vocabulary proficiency. Meanwhile, a questionnaire was designed to understand the learning strategies of junior high school students and understand their vocabulary learning difficulties. In this way, the eight student teachers had ideas about how to implement their plan and action accordingly, and then reflected upon the outcomes of their actions (Burns, 2010). During this introductory period, they gained a deeper knowledge about the school. This helped them to adopt more appropriate teaching approaches in order to meet the needs of the school students and improve their English language learning.

All of the work undertaken in the first stage shaped the next stage, which was to train the student teachers and set about implementing their teaching plans. The student teachers designed their lesson plans in detail in order to enhance their teaching practice. Significant progress was made during the second action research cycle due to the intensive teaching practice and discussion after each tutorial teaching. The reflection caused them to think back carefully on their teaching actions and adjust their original teaching approach (McNiff, 1993; Whitehead, 2009). Although they used a tutorial teaching approach, one student teacher gave a brief lecture to the whole group on the main points at the beginning and then each of the other seven student teachers tutored two students. In this way, junior high students got a better understanding about what they were going to review.

The focus of the third stage was to examine the student teachers' tutorial teaching practice. Through intensive practice, they came to comprehend how a tutorial teaching approach directs not only individual student learning but also a teacher's classroom instruction to meet the needs of individual learners. They also questioned how this knowledge could improve vocabulary teaching practices and then sought ways to achieve this goal. The student teachers began to see how to involve students in understanding the link between the assessment of students' vocabulary and the resulting specific actions that were identified to successfully move students to their next stage of vocabulary development.

\subsection{Research Participants}

The participants in this study were 16 high school students in an EFL environment. The students had five-hours of English a week and spent a lot of time learning vocabulary, idioms and sentence patterns. If there were several long and complex sentences in a lesson, junior high school teachers often spent a great deal of time to analysis the structure. However, some students still had difficulty on learning vocabulary and reading context in the coursebook. Therefore, they were chosen to participate in this project.

Moreover, eight student teachers participated in the whole teaching process. They assisted the junior high school students in learning vocabulary using five different approaches using phonetic symbols, games, flash cards, sentence making and songs in the tutorial.

In addition, the tutor of the eight student teachers regularly discussed with them their teaching practice in the tutorials.

\subsection{The Course Design}

The tutorial class met thirty minutes a week for a total of nine weeks at a junior high school. The teaching materials consisted of a coursebook, handouts, flashcards and songs. The student teachers designed a series of activities, based on the coursebook vocabulary list to teach the junior high school students English vocabulary memorization methods and techniques. Moreover, they provided a handout after each class to keep them from being distracted by taking notes in class. In addition, posters, flashcards and songs were used to motivate students and create interest.

\subsection{Instruments}

In keeping with self-reflective research, varied data were employed to help student teachers examine their practice. Both qualitative and quantitative data were used to assess the research questions. First, a pre-test and a post-test using vocabulary quizzes were given in order to evaluate the English proficiency of the junior high school students. This was helpful for subsequent tutorial course design. Secondly, a questionnaire was used to 
investigate the junior students' perception of the tutorial teaching approach. The questionnaire consisted of a number of closed-ended items with specific response categories and an open-ended item. Thirdly, the student teachers conducted interviews with the students after each class to get a deeper understanding of any questions they might have concerning class activities. Because there were only 16 high school students, each student teacher interviewed only two of them at a time. Usually, high school students are not willing to discuss their learning difficulties with their class teachers. However, these students appreciated a discussion about their individual learning problems with their tutor. The main reason for this was the knowledge that tutor was there to help them and not to grade them. In other words, these young learners felt potentially at ease to suggest positive or negative changes to the tutors. This factor increased the reliability and the validity of having individual interviews.

In this way, student teachers could discover whether the students preferred the teaching method or whether the method helps them study easily or not so that they could adjust their teaching approach. Finally, the student teachers not only wrote teaching journals after each class but also took notes during their discussion. The journals included what the student teachers had seen, what kind of problems they had encountered, what they had learned from those problems in those situations, and what they had learned from the students.

\section{Findings and Discussions}

This section presents the findings of this study. The results and discussion are addressed in terms of the teachers' and students' responses to the tutorial teaching approach.

\subsection{Learners' Perspective of a Tutorial Teaching Approach}

\section{Research Question 1}

What did the students taught by these student teachers perceive about the tutorial teaching approach?

Table 4.1. Learners' perspective of a tutorial teaching approach

\begin{tabular}{llll}
\hline \multicolumn{2}{l}{ Question: Is tutorial teaching helpful? } & & \\
\hline \multicolumn{2}{l}{ Before tutorial teaching } & After tutorial teaching & \\
Yes & No & Yes & No \\
$75 \%$ & $25 \%$ & $100 \%$ & 0 \\
\hline
\end{tabular}

According to Table 4.1, $25 \%$ of the students disagree that small group teaching was helpful improving their English ability. They did not think it different from whole class teaching. However, they changed their opinions after tutorial teaching. The data showed that tutorial teaching is better than whole class teaching. All the students liked small group teaching was preferred to whole class teaching. They felt more joyful than ahead of the tutorial teaching. Moreover, they enjoyed interacting with their tutorial teachers. Interactionist learning theory emphasises communication between learners and instructors instead of When the utterances produced by learners (Ortega, 2011). The interactionist regards language development as the result both of input factors and of innate mechanisms (Gass \& Mackey, 2007). In other words, a learning process combines both an external factor such as outside linguistic environment and an internal factor like learners' mental ability. When learners felt stress-free, they had more confidence to answer questions.

Table 4.2. Learners' perspective of English learning

\begin{tabular}{llll}
\hline Question: Are you confident in English class? & & \\
\hline Before tutorial teaching & & After tutorial teaching & \\
Yes & No & Yes & No \\
$19 \%$ & $81 \%$ & $29 \%$ & $71 \%$ \\
\hline
\end{tabular}

According to Table 4.2, 81\% of the participants reported that they were nervous in English classes. One of the reasons was that they often had a lot of quizzes in English classes. After the tutorial teaching, $71 \%$ of the participants were still worried about English classes. At least 10\% of the students had better learning motivation after tutorial teaching. 
Before this project was conducted, the majority of the junior high school students simply followed an English teacher's instruction in a class of thirty students. They did not have any chance to experience a tutorial teaching situation. As student teachers used a lot of interesting activities to inspire learners, the students had a higher motivation to learn English. This was why the small class teaching was the better choice for them.

\subsection{Student Teachers' Perspective of Tutorial Teaching}

\section{Research Question 2}

What did the student teachers think of what they had learned to teach at the end of their initial teaching practice?

This research question is answered over the three stages.

In each of the sections below there were a few instances of the student teachers' reflective comments.

1. Identify learners' learning needs in the area of language.

At the beginning of the project, the student teachers spent a lot of time together discussing lesson plans and teaching content. Frankly speaking, they were not confident in teaching junior high school students because most of them did not have any teaching experience. Therefore, they used a pre-test quiz and a questionnaire to understand what to teach and how to manage the teaching processes. They described their concerns about their teaching in their research journals.

The students in this class had a problem. They could neither to follow their teacher nor make sense of the coursebook. They disliked English and were not interested in studying it. They needed a tutor to coach them individually. (Student teacher Tinka)

I started with a number of teaching ideas with a specific group of students but I was not really sure how to facilitate this. (Student teacher May)

Initially, I planned to teach high school students vocabulary but I found that many of them actually did not know how to pronounce a word. Thus, I had to change my teaching approaches. (Student teacher Peter)

We thought that students had not learned well because of a large class teaching approach. The student asked a lot of questions but few of them remembered the answers. Compared to the small group teaching, they did not focus on the specific content. (Student teacher Jimmy)

At this stage, many "what" and "how" questions were raised in teaching. In other words, these student teachers were concerned with understanding and improving their own practices and the impact they had on their students. During the same stage, the student teachers learned how to make decisions and how to identify their thinking gaps (Postlethwaite \& Haggarty, 2012). Therefore, they proposed a nine-week lesson plan and stated in detail each of the teaching points they were going to apply in class.

When adults undertake to learn something autonomously, they begin to use their concrete experiences to reflect and observe (Kolb, 1983; Richards \& Farrell, 2011). From these observations and reflections they obtain abstract concepts, generalisations, and models to be tested in new situations. Finally, the new experiences gained from the experimental phase are linked with the original concrete experience.

2. Teach language lessons to address those needs.

The project with ongoing teaching journals and regular group discussion was a catalyst for more systematic thinking about particular teaching. It provided a focus for introducing changes and brought a new dynamic into the relationship between teachers and students.

At first, we used posters to present phonetic symbols so students were clear about what we were going to teaching. It was also convenient for teachers to explain the symbols. Later, we asked the students to paint black and white flash cards. When learners felt interested, they would like to learn. (Student teacher Jasmine)

It was important to check the material which we wanted to teach students because we had found two mistakes before the class began. We modified the material right away. We thought at least three of us had to check it out.

(Student teacher Jimmy)

Before class, I told my students that we could play a small game after we learn vocabulary. The students were so excited that they could concentrate more on learning vocabulary. After class, we found that students liked to use an active method to learn English. (Student teacher Doris)

I thought a competition game was a great way to learn. The students would help their group members win 
the game. In this way, they not only enhanced their English ability but also learned to be cooperative. (Student teacher Anne)

3. Apply useful strategies to tutoring an individual student.

During the nine weeks, the concerns of the student teachers changed over time and broadened from the immediate demands of their teaching actions to the students' needs for their teaching content (Phillips \& Carr, 2010). This project led them into new areas of reflection and for some of the participants developed a strong sense of confidence and motivation.

The tutorial teaching seems better than classroom teaching and the tutorial teaching is more useful. Each teacher could clearly know a student's learning situation. (Student teacher Jasmine)

If a teacher asked a question and almost every student knew the answer, it meant the teacher taught well and the teacher would feel a great sense of achievement (Student teacher Angelin)

When their English teacher told us that their English vocabulary test results had improved, we felt very joyful at that good news. We hope that the students can use our teaching methods to remember vocabulary in their future learning. (Student teacher Peter)

The tutorial teaching approach was implemented by eight student teachers on teaching practice for the first time. Although their tutorial approach was used only for nine weeks, they discussed their teaching practice and made adjustments throughout the period. The student teachers thought that the learners paid more attention to learning with a tutorial teaching approach. When a student did not understand the content, he or she could immediately raise questions and got instant feedback. The student teachers got feedback from learners and devised solutions at every step of the process. This tutorial approach exposed students' learning weaknesses and offered them an opportunity to correct mistakes at any time. Moreover, this approach provided a system of monitoring their progress more accurately.

\section{Conclusion}

In conducting this project, the student teachers learned pedagogical methods to teach students how to remember vocabulary easily and to identify those most suitable for junior high school students. Furthermore, the student teachers learned how to solve various problems they might encounter when teaching. Finally, it can be said that the tutorial teaching experience helps provide students with a more holistic view of the learning process, throughout their degree course, based on practical experience.

\section{References}

Ashwin, P. (2005). Variation in students' experiences of the Oxford Tutorial. Higher Education, 50(4), 631-644. http://dx.doi.org/10.1007/s10734-004-6369-6

Brookfield, S. (2000). The concept of critically reflective practice. San Francisco: Jossey-Bass.

Burns, A. (2010). Doing Action Research in English Language Teaching: A Guide for Practitioners. New York: Routledge.

Gass, S. M., \& Mackey, A. (2007). Input, interaction, and output in second language acquisition. In B. VanPatten, \& J. Williams (Eds.), Theories in second language acquisition: An introduction (pp. 173-196). Mahwah, NJ: Erlbaum.

Gow, L., \& Kember, D. (1993). Conceptions of teaching and their relation to student learning. British Journal of Educational Psychology, 31, 93-97.

Kolb, D. A. (1983). Experiential Learning: Experience as the Source of Learning and Development. New York: Prentice Hall.

Larrivee, B. (2000). Transforming Teaching Practice: Becoming the critically reflective teacher. Reflective Practice, 1(3), 293. http://dx.doi.org/10.1080/713693162

McNiff, J. (1993). Teaching as Learning: An Action Research Approach. London: Routledge. http://dx.doi.org/10.4324/9780203187999

Norton, L. (2009). Action Research in Teaching and Learning: A practical guide to conducting pedagogical research in universities. Oxon: Routledge.

Ortega, L. (2011). SLA after the social turn. In D. Atkinson (Ed.), Alternative Approaches to Second Language Acquisition. London: Routledge. 
Osterman, K. F. (1990). Reflective Practice: A New Agenda for Education. Education and Urban Society, 22(2), 133-152. http://dx.doi.org/10.1177/0013124590022002002

Phillips, D., \& Carr, K. (2010). Becoming a Teacher through Action Research: Process, Context, and Self-Study, (2nd ed.). New York: Routledge.

Pollard, A. (2008). Reflective teaching: evidence-informed professional practice (3rd ed.). London: Continuum.

Postlethwaite, K., \& Haggarty, L. (2012). Student teachers' thinking about learning to teach: a study of student teachers of mathematics and science at the end of their initial training. Research Paper in Education, 27(3), 263-284. http://dx.doi.org/10.1080/02671522.2010.501906

Prosser, M., \& Trigwell, K. (1997). Relations between perceptions of the teaching environment and approaches to teaching. British Journal of Educational Psychology, 67, 25-35. http://dx.doi.org/10.1111/j.2044-8279.1997.tb01224.x

Prosser, M., \& Trigwell, K. (1999). Understanding learning and teaching: The experience in higher education. Buckingham: Open University Press.

Richards, J., \& Farrell, T. (2011). Practice Teaching: A Reflective Approach. Cambridge: Cambridge University Press.

Schön, D. (1983). The reflective practitioner: How professionals think in action. New York: Basic Books.

Schön, D. (1987). Educating the Reflective Practitioner: Toward a New Design for Teaching and Learning in the Professions. San Francisco: Jossey-Bass.

Stringer, E., Christensen, L., \& Baldwin, S. (2010). Integrating Teaching, Learning, and Action Research: Enhancing Instruction in the K-12 Classroom. Los Angeles: Sage.

Wallace, M. (1998). Training Foreign Language Teachers: A reflective approach. Cambridge: Cambridge University Press.

Whitehead, J. (2009). Generating living theory and understanding in action research studies. Action Research, 7(1), 85-99.

Whitehead, J., \& McNiff, J. (2006). Action Research: Living Theory, London: Sage.

Zeichner, K. M., \& Liston, D. P. (1987). Teaching student teachers how to reflect. Harvard Educational Review, 57(1), 23-48.

\section{Copyrights}

Copyright for this article is retained by the author(s), with first publication rights granted to the journal.

This is an open-access article distributed under the terms and conditions of the Creative Commons Attribution license (http://creativecommons.org/licenses/by/3.0/). 